\title{
PENGARUH WORD OF MOUTH (WOM), KUALITAS PELAYANAN, KEAMANAN DAN KEPERCAYAAN TERHADAP KEPUTUSAN KONSUMEN MENGGUNAKAN JASA TRANSPORTASI ONLINE GRABBIKE DI KOTA SURAKARTA
}

\author{
Yasmin Rajaa Nabilah, Andri Nurtantiono \\ Sekolah Tinggi Ilmu Ekonomi Surakarta \\ Email : andristies@yahoo.com
}

\begin{abstract}
The purpose of this study was to determine the effect of Word of Mouth, Service Quality, Security, and Trust on Consumer Decisions using GrabBike Online Transportation Services in Surakarta City. From distributing questionnaires to 100 respondents, results show that Word of Mouth, Service Quality, and Trust have a significant effect on consumer decisions while security has no significant effect on consumer decisions.
\end{abstract}

Keywords: Consumer Decisions, Word of Mouth, Service Quality, Security, Trust

\section{PENDAHULUAN}

Transpotasi online mulai muncul pada pertengahan tahun 2015. Di mulai dari ojek online yang saat ini sudah hampir ada di seluruh wilayah Indonesia, diantaranya Go-Jek, Grab, dan juga Uber. Tingginya minat konsumen terhadap transportasi online membuat perusahaan berbasis jasa transportasi online tersebut berlomba-lomba menciptakan inovasi untuk menarik minat konsumen.

Grab (sebelumnya dikenal sebagai GrabTaxi merupakan perusahaan transportasi online dari Singapura yang telah beroperasi di Indonesia sejak 2015 dengan nama GrabBike (money.id/2016). Pada tahun 2017, Grabbike mulai beroperasi di kota Solo dan sekitarnya dan menambah persaingan transportasi daring atau online Solo yang kian ketat. Kendati demikian perluasan pasar ojek online Grab secara keseluruhan lebih sedikit dibandingkan dengan ojek online Gojek.

Sebagai pemain baru, beberapa langkah strategis dilakukan seperti menawarkan harga yang lebih murah dengan kualitas layanan yang sama dan keamanan yang tetap terjaga, atau prosedur pembayaran dan pengisian pulsa pelanggan melalui aplikasi OVO yang sudah popular sebelumnya, yang mampu mencuri pelanggan dari Gojek, dan jika ini menyebar ke konsumen yang lain dan mampu merebut kepercayaan dari masyarakat, maka akan menaikkan pangsa pasar GraBbike. Atas dasar inilah, peneliti mencoba meneliti pengguna Grabbike, dan pengaruh Word of Mouth, Kualitas Pelayanan, Keamanan, dan Kepercayaan terhadap Keputusan mereka.

Setelah melakukan penyebaran kuesioner terhadap 100 responden dari masyarakat Kota Surakarta yang pernah menjadi pengguna jasa GrabBike, berikut beberapa klasifikasi responden (Tabel 1) : 
Tabel 1

Identitas Responden

\begin{tabular}{|c|c|c|c|c|}
\hline No. & $\begin{array}{c}\text { Latar } \\
\text { Belakang } \\
\text { Responden }\end{array}$ & Identitas & Jumlah & $\begin{array}{c}\text { Presentase } \\
(\%)\end{array}$ \\
\hline \multirow[t]{6}{*}{1} & Alamat & Karangasem & 16 & 16,3 \\
\hline & & Laweyan & 41 & 40,8 \\
\hline & & Kadipiro & 3 & 3,4 \\
\hline & & Banjarsari & 15 & 15 \\
\hline & & Jebres & 17 & 17 \\
\hline & & Serengan & 8 & 7,5 \\
\hline \multirow[t]{3}{*}{2} & Usia & $15-18$ tahun & 5 & 4,8 \\
\hline & & $19-25$ tahun & 86 & 85,7 \\
\hline & & $>25$ tahun & 9 & 9,5 \\
\hline \multirow[t]{5}{*}{3} & Pekerjaan & Pelajar / Mahasiswa & 82 & 82,3 \\
\hline & & Karyawan & 10 & 9,5 \\
\hline & & Wirausaha & 5 & 4,8 \\
\hline & & Guru & 2 & 2 \\
\hline & & Lawyer & 1 & 0,49 \\
\hline \multirow[t]{4}{*}{4} & Frekuensi & Seminggu $1 \mathrm{x}$ & 50 & 50,3 \\
\hline & & Seminggu $2 \mathrm{x}$ & 10 & 9,5 \\
\hline & & Seminggu $3 x$ & 10 & 9,5 \\
\hline & & $>3 x$ dalam Seminggu & 30 & 30,6 \\
\hline
\end{tabular}

Sumber : Data diolah, 2020

\section{TINJAUAN PUSTAKA}

\section{Word of Mouth}

Konsumen yang menjadi pengguna dari suatu produk akan mengalami pengalaman baik buruk ataupun baik dari produk atau jasa yang mereka beli. Jika pengalaman yang dirasakan baik, mereka tidak hanya akan mengatakan jujur dengan apa yang mereka dapatkan, tetapi mereka bahkan juga mau memberikan pujian jika mendapatkan hasil yang maksimal. Selain itu mereka juga akan dengan senang hati merekomendasikan ke orang lain khususnya orang terdekat. Komentar,pujian, serta kemungkinan memberikan rekomendasi kepada orang lain menjadi pemahaman yang berkaitan dengan Word of Mouth sebagaimana disampaikan oleh Hasan (2010). 


\section{Kualitas Pelayanan}

Kualitas Layanan sebagaimana dikatakan Parasuraman dalam Lupiyoadi (2014) bermakna seberapa perbedaan antara harapan dan kenyataan yang pelanggan rasakan terhadap layanan yang mereka terima. Kualitas pelayanan dapat diketahui dengan cara membandingkan persepsi pelanggan atas layanan yang benar-benar mereka terima dengan layanan sesungguhnya yang mereka harapkan.

Bila jasa yang pelanggan terima dianggap sesuai dengan yang diharapkan, menjadikan kualitas jasa dipersepsikan baik dan memuaskan. Jika jasa yang diterima mampu melampaui harapan pelanggan, hal ini yang mestinya sangat diharapkan oleh pelanggan, meski seringkali dianggap ideal. Namun sebaliknya jika jasa yang diterima pelanggan lebih rendah dari pada yang diharapkan, kualitas jasa dianggap buruk (Tjiptono, 2005).

\section{Keamanan}

Keamanan adalah kemampuan dalam melakukan pengontrolan dan penjagaan keamanan atas transaksi data. Lebih lanjut Park dan Kim mengatakan bahwa jaminan keamanan berperan penting dalam pembentukan kepercayaan dengan mengurangi perhatian konsumen tentang penyalahgunaan data pribadi dan transaksi data yang mudah rusak. (Suryani, 2013). Sebagaimana Kualitas layanan yang terbentuk atas jasa yang diberikan dan diterima oleh pelanggan, maka keamanan juga sangat tergantung kepada upaya aktif dari pengelola jasa atau penghasil produk.

\section{Kepercayaan}

Menurut Sumarwan (2011), "Kepercayaan adalah kekuatan bahwa suatu produk memiliki atribut tertentu". Mowen dan Minor mendefiniskan, "Kepercayaan konsumen sebagai semua pengetahuan yang dimiliki oleh konsumen, dan semua kesimpulan yang dibuat oleh konsumen tentang objek, atribut dan manfaatnya”. Kepercayaan konsumen dibentuk oleh masyarakat itu sendiri melalui beberapa pengetahuan yang dimiliki. Pengetahuan terkait citra, reputasi dan Kualitas Pelayanan memiliki kekuatan untuk membentuk Kepercayaan.

\section{Keputusan Pembelian}

Keputusan Pembelian adalah keputusan atas pilihan suatu tindakan dari dua pilihan alternatif atau lebih. Dari berbagai faktor yang mempengaruhi konsumen dalam melakukan pembelian suatu produk atau jasa, biasanya konsumen selalu mempertimbangkan kualitas, harga dan produk yang sudah dikenal oleh masyarakat (Sangadji dan Sopiah, 2013). Proses yang terjadi dalam pengambilan keputusan pembelian pada awalnya berliku, mulai mencari informasi sebanyak-banyaknya terutama jika produknya produk baru, menentukan keputusan hingga akhirnya keputusan itu menjadi sebuah hal yang rutin dilakukan tanpa banyak pertimbangan. 


\section{METODOLOGI PENELITIAN}

Dengan jumlah populasi masyarakat kota Surakarta sebanyak 512.226 jiwa, digunakan teknik formula Slovin, dan diperoleh sampel 100 responden. Instrumen pengumpul data dengan Kuesioner yang diadaptasi dari beberapa sumber, dan setelah data terkumpul, dianalisis dengan teknik analisis kuantitatif, yaitu analisis Regresi Berganda.

Definisi operasional variabel dalam penelitian ini berikut indikatornya diperlihatkan dalam tabel 2 :

\section{Tabel 2}

Definisi Operasional dan Indikator Variabel

\begin{tabular}{|c|c|c|c|}
\hline No & Variabel & Definisi Operasional & Indikator \\
\hline 1 & $\begin{array}{l}\text { Word of } \\
\text { Mouth } \\
\text { (X1) }\end{array}$ & $\begin{array}{l}\text { Word of Mouth } \\
\text { merupakan komunikasi } \\
\text { yang bisa berbentuk } \\
\text { suatu komentar atau } \\
\text { rekomendasi yang } \\
\text { disebarkan konsumen } \\
\text { menurut pengalaman, } \\
\text { dan mempunyai } \\
\text { pengaruh yang besar } \\
\text { terhadap pengambilan } \\
\text { keputusan oleh pihak } \\
\text { lain. }\end{array}$ & $\begin{array}{l}\text { 1. Talkers (pembicara) } \\
\text { 2. Topics (topik) } \\
\text { 3. Tools (alat) } \\
\text { 4. Talkingpart (partisipasi) } \\
\text { 5. Tracking (pengawasan) } \\
\text { Sernovitz (2012) }\end{array}$ \\
\hline 2 & $\begin{array}{c}\text { Kualitas } \\
\text { Pelayanan } \\
\quad \text { (X2) }\end{array}$ & $\begin{array}{l}\text { Kualitas Pelayanan } \\
\text { adalah segala bentuk } \\
\text { aktivitas yang } \\
\text { dilakukan oleh } \\
\text { perusahaan guna } \\
\text { memenuhi harapan } \\
\text { konsumen. }\end{array}$ & $\begin{array}{l}\text { - Reliability (Keandalan) } \\
\text { - Responsiveness (daya } \\
\text { tanggap) } \\
\text { - Assurance (jaminan) } \\
\text { - Empathy (empati) } \\
\text { - Tangible (produk-produk } \\
\text { fisik) } \\
\text { Jasfar (2009) }\end{array}$ \\
\hline 3 & $\begin{array}{c}\text { Keamanan } \\
(\text { X3) }\end{array}$ & $\begin{array}{l}\text { Keamanan merupakan } \\
\text { rasa aman, bebas, } \\
\text { terlindung dari bahaya, } \\
\text { dan ketenangan yang } \\
\text { diterima oleh } \\
\text { konsumen. }\end{array}$ & $\begin{array}{l}\text { 1) Terjaminnya transaksi. } \\
\text { 2) Kemudahan transaksi } \\
\text { melalui COD (Cash On } \\
\text { Delivery) ataupun transfer. } \\
\text { 3) Bukti transaksi melalui } \\
\text { nomor resi pengiriman. }\end{array}$ \\
\hline
\end{tabular}




\begin{tabular}{|c|c|c|c|}
\hline & & & $\begin{array}{l}\text { 4) Citra penjual online. } \\
\text { 5) Kualitas produk. }\end{array}$ \\
\hline 4 & $\begin{array}{c}\text { Kepercayaan } \\
\text { (X4) }\end{array}$ & $\begin{array}{l}\text { Kepercayaan konsumen } \\
\text { adalah kesediaan satu } \\
\text { pihak menerima resiko } \\
\text { dari pihak lain } \\
\text { berdasarkan keyakinan } \\
\text { dan harapan bahwa } \\
\text { pihak lain akan } \\
\text { melakukan tindakan } \\
\text { sesuai yang diharapkan, } \\
\text { meskipun kedua belah } \\
\text { pihak belum mengenal } \\
\text { satu sama lain }\end{array}$ & $\begin{array}{l}\text { 1. Kejujuran penjual dalam } \\
\text { bertransaksi } \\
\text { 2. Tanggungjawab penjual } \\
\text { kepada pembeli } \\
\text { 3. Kepercayaan bahwa } \\
\text { perusahaan memiliki } \\
\text { reputasi yang baik } \\
\text { Nuraini (2009) }\end{array}$ \\
\hline 5 & $\begin{array}{c}\text { Keputusan } \\
\text { Konsumen } \\
\text { (Y) }\end{array}$ & $\begin{array}{l}\text { Keputusan pembelian } \\
\text { konsumen merupakan } \\
\text { suatu proses pemilihan } \\
\text { salah satu dari beberapa } \\
\text { alternatif penyelesaian } \\
\text { masalah dengan tindak } \\
\text { lanjut yang nyata. }\end{array}$ & $\begin{array}{l}\text { 1. Rutinitas konsumen } \\
\text { dalam melakukan } \\
\text { pembelian } \\
\text { 2. Kualitas yang diperoleh } \\
\text { dari suatu keputusan } \\
\text { pembelian, } \\
\text { 3. Komitmen atau loyalitas } \\
\text { konsumen }\end{array}$ \\
\hline
\end{tabular}

\section{HASIL PENELITIAN DAN PEMBAHASAN}

\section{Uji Instrumen Data}

Uji instrumen data berupa validitas dan reliabilitas data. Pada uji validitas dinyatakan bahwa data valid dikarenakan hasil uji pada variabel Word of Mouth, Kualitas Pelayanan , Keamanan, Kepercayaan, dan Keputusan Pembelian memiliki signifikansi < 0,05. Pada uji reliabilitas, menunjukkan hasil Cronbach's Alpha memiliki nilai $>0,60$, sehingga dapat dinyatakan reliabel.

\section{Uji Asumsi Klasik}

Pada uji normalitas menggunakan metode Klomogorov-Smirnov nilai signifikansi 0,145 > 0,05 memberi petunjuk bahwa data berdistribusi normal. Pada uji multikolinieritas dapat diketahui bahwa nilai nilai VIF untuk semua variabel bebas $<10$, maka tidak terjadi 
multikolinieritas. Sedangkan pada uji heteroskedastisitas dengan nilai probabilitas (Sig.) lebih besar dari nilai $\alpha=0,05$ dan bebas dari gejala heteroskedastisitas.

\section{Analisis Regresi Linier Berganda}

Berdasarkan hasil perhitungan yang telah dilakukan, diperoleh rumus

$Y=-2,342+0,358 X 1+0,315 X 2+0,061 X 3+0,477 X 4$

Nilai konstanta sebesar -2,342 atau bernilai negatif, hal ini berarti bahwa dengan tidak adanya Word of Mouth (WOM), Pelayanan yang berkualitas, jaminan Keamanan dan ketidak adanya Kepercayaan menyebabkan penurunan Keputusan Konsumen. Nilai koefisien variabel Word of Mouth (X1) memiliki tanda koefisien positif, artinya apabila Word of Mouth meningkat, maka akan meningkatkan Keputusan Konsumen. Nilai koefisien variabel Kualitas Pelayanan (X2) memiliki tanda koefisien positif, artinya apabila Kualitas Pelayanan ditingkatkan, akan meningkatkan Keputusan Konsumen. Nilai koefisien variabel Keamanan (X3) memiliki tanda koefisien positif, artinya apabila Keamanan ditingkatkan, akan terjadi peningkatan Keputusan Konsumen. Demikian pula akan terjadi peningkatan Keputusan saat ada peningkatan.

\section{Uji t}

Dari keempat variable bebas, tiga diantaranya signifikan berpengaruh pada variable terikat. Yang pertama uji t antara Word of Mouth dengan Keputusan Konsumen menggunakan Jasa Transportasi Online GrabBike di Surakarta sebesar 3,207 > $\mathrm{t}_{\text {tabel }}(1,985)$ dan sig 0,002 < 0,05, memberikan tanda bahwa Word of Mouth berpengaruh terhadap Keputusan Konsumen. Kedua uji $t$ antara Kualitas Pelayanan dengan Keputusan Konsumen menggunakan Jasa Transportasi Online GrabBike di Surakarta sebesar 2,670 < $\mathrm{t}_{\text {tabel }}(1,985)$ dan sig 0,009 > 0,05, memberikan tanda Kualitas Layanan berpengaruh terhadap Keputusan Konsumen. Hasil uji t ketiga antara Kepercayaan dengan Keputusan Konsumen menggunakan Jasa Transportasi Online GrabBike di Surakarta sebesar 3,390 $>t_{\text {tabel }}(1,985)$ dan sig 0,001 > 0,05 bermakna Kepercayaan berpengaruh terhadap Keputusan Konsumen. Sedangan untuk hasil analisis Uji t antara Keamanan dengan Keputusan Konsumen menggunakan Jasa Transportasi Online GrabBike di Surakarta menunjukkan hasil yang tidak signifikan dengan nilai sig 0,660>0,05 dan t hitung sebesar $0,441<t_{\text {tabel }}(1,985)$

\section{Koefisien Determinasi}

Adjusted R Square sebesar 0,548 menjadi petunjuk bahwa variable bebas Word of Mouth, Kualitas Pelayanan , Keamanan ,dan Kepercayaan berkontribusi terhadap Keputusan Konsumen sebesar 54,8\%.

\section{Pembahasan}

1) Pengaruh Word of Mouth terhadap Keputusan Konsumen

Hasil pengujian hipotesis menunjukkan bahwa word of mouth berpengaruh signifikan terhadap keputusan konsumen menggunakan GrabBike. Hasil ini dapat menjadi sebuah 
tolak ukur konsumen bahwa Grab sudah dikenal masyarakat Surakarta dan mampu menjadi sebuah transportasi online yang mudah digunakan.

2) Pengaruh Kualitas Pelayanan terhadap Keputusan Konsumen

Hasil pengujian hipotesis menunjukkan kualitas pelayanan berpengaruh signifikan terhadap keputusan konsumen menggunakan GrabBike. Hasil ini dapat menjadi sebuah tolak ukur konsumen bahwa perusahaan Grab mampu memberikan layanan yang berkualitas terhadap mereka.

3) Pengaruh Keamanan terhadap Keputusan Konsumen

Hasil uji $\mathrm{t}$ mendapatkan hasil bahwa variabel keamanan tidak berpengaruh signifikan terhadap keputusan konsumen GrabBike. Hasil ini menjadi petunjuk bahwa faktor keamanan tidak diperhatikan konsumen pengguna Grabbike

4) Pengaruh Kepercayaan terhadap Keputusan Konsumen

Hasil pengujian hipotesis menunjukkan bahwa kepercayaan berpengaruh signifikan terhadap keputusan konsumen GrabBike. Hasil ini menjadi bukti bahwa Grabbike dipercaya oleh konsumen sebagai penyedia jasa transportasi online yang dapat mereka pilih saat mereka membutuhkan.

\section{KESIMPULAN}

1) Word of Mouth berpengaruh signifikan terhadap Keputusan Konsumen menggunakan GrabBike di Kota Surakarta.

2) Kualitas Pelayanan berpengaruh signifikan terhadap Keputusan Konsumen menggunakan GrabBike di Kota Surakarta.

3) Keamanan tidak berpengaruh signifikan terhadap Keputusan Konsumen menggunakan GrabBike di Kota Surakarta.

4) Kepercayaan berpengaruh signifikan terhadap Keputusan Konsumen menggunakan GrabBike di Kota Surakarta.

\section{Saran}

1) Hasil data yang diperoleh dari rekapitulasi pernyataan Word of Mouth diketahui bahwa saya mendapatkan informasi tentang Grab dari orang lain dengan hasil 67\%, maka disarankan untuk perusahaan memperluas jangkauan konsumen sehingga konsumen dapat mengetahui tentang Grab dan dapat merekomendasikan Grab sebagai transportasi layanan jasa yang baik.

2) Hasil data yang diperoleh dari rekapitulasi pernyataa Kualitas Pelayanan diketahui bahwa langkah Grab dalam memberikan jaminan asuransi untuk kecelakaan sangat baik dengan hasil 54\%, maka disarankan untuk perusahaan lebih meningkatkan jaminan asuransi terhadap driver atau konsumen yang mengalami kecelakaan, dengan cara mempermudah klaim atas hak asuransi yang akan didapatkan korban kecelakaan.

3) Hasil data yang diperoleh dari rekapitulasi pernyataan Kepercayaan diketahui bahwa Grab selalu bertanggung jawab terhadap kesalahan yang dilakukan oleh driver dengan hasil 64\%, maka disarankan untuk perusahaan merespon dengan baik dan cepat setiap keluhan konsumen, serta segera menyelesaikan permasalahan yang terjadi antara driver dengan konsumennya. 


\section{REFERENSI}

Hasan, A. (2010). Marketing Dari Mulut Ke Mulut. Yogyakarta: Media Pressindo.

Jasfar, Farida. 2009. Manajemen Jasa : Pendekatan Terpadu. Jakarta : Ghalia Indonesia.

Lupiyoadi, R. (2014). Manajemen Pemasaran Jasa. Edisi 3. Jakarta: Salemba Empat.

Nuraini. 2009. “Analisis Pengaruh Kualitas Produk, Kualitas Pelayanan, Desain Produk, Harga Dan Kepercayaan Terhadap Loyalitas Pelanggan”. Skripsi Fakultas Ekonomi Universitas Dipenegoro.

Sangadji, E. M., \& Sopiah. (2013). Perilaku Konsumen: Pendekatan Praktis Disertai : Himpunan Jurnal Penelitian. Yogyakarta: Andi.

Sernovitz, A. (2012). Word of Mouth Marketing How Smart Companies Get People Talking. Austin: Greenleaf Book Group Press.

Sumarwan, U. (2011). Perilaku Konsumen : Teori dan Penerapannya Dalam Pemasaran. Bogor: Ghalia Indonesia.

Suryani, T. (2013). Perilaku Konsumen di Era Internet. Yogyakarta: Graha Ilmu.

Tjiptono, F. (2005). Pemasaran Jasa, Edisi pertama. Yogyakarta: Bayumedia Publishing. 